\title{
Taxes and Capital Structure
}

\author{
Mara Faccio and Jin $\mathrm{Xu}^{*}$
}

\begin{abstract}
We use nearly 500 shifts in statutory corporate and personal income tax rates as natural experiments to assess the effect of corporate and personal taxes on capital structure. We find both corporate and personal income taxes to be significant determinants of capital structure. Based on ex post observed summary statistics, across Organisation for Economic Co-Operation and Development (OECD) countries, taxes appear to be as important as other traditional variables in explaining capital structure choices. The results are stronger among corporate tax payers, dividend payers, and companies that are more likely to have an individual as the marginal investor.
\end{abstract}

\section{Introduction}

In this paper, we address an old question in financial economics: Do taxes affect corporate capital structure choices? Despite strong theoretical reasons why taxes should matter (e.g., Modigliani and Miller (1963), Miller (1977), and DeAngelo and Masulis (1980)), discouraging results in earlier empirical studies lead Myers (1984) to state in his well-known Presidential Address to the American Finance Association that "[w]e don't know" how "firms choose their capital structures" as there is "no study clearly demonstrating that a firm's tax status has predictable, material effects on its debt policy" (pp. 575, 588).

More recent papers (e.g., Desai, Foley, and Hines (2004), Fan, Titman, and Twite (2012), Graham (1996a), (1996b), (1999), and MacKie-Mason (1990)) establish a more solid statistical connection between taxes and capital structure choices. However, the existing evidence on the relation between taxes and capital structure is still predominantly cross sectional. A standard criticism of the welldocumented cross-sectional correlation between debt and taxes is that it may

*Faccio, mfaccio@purdue.edu, Krannert School of Management, Purdue University, West Lafayette, IN 47906; Xu (corresponding author), xujin@vt.edu, Pamplin College of Business, Virginia Polytechnic Institute and State University, Blacksburg, VA 24061. We thank Sylvain Bourjade, Murillo Campello (associate editor and referee), Dave Denis, Diane Denis, John Graham, Rick Green, Byoung Hwang, Da Ke, Seoyoung Kim, Andrew MacKinlay, Paul Malatesta (the editor), Maria-Teresa Marchica, John McConnell, Roberto Mura, Bill O’Brien, David Offenberg, David Stolin, Deniz Yavuz, and seminar participants at the 2011 Corporate Governance Workshop (Toulouse Business School), the 2011 Annual Texas Finance Festival, the 2012 Society for Financial Studies (SFS) Finance Cavalcade, Michigan State University, Nanyang Technological University, and University of Texas at Dallas for comments. We also thank Steve McKeon for excellent research assistance. 
simply reflect unobservable characteristics that affect both taxes and capital structure. Furthermore, as Graham (2003) points out, from an empirical standpoint, the magnitude of the documented effect of taxes on capital structure is "not always large" (p. 1119).

The key contribution of this paper is the use of a multitude of shifts in statutory tax rates, both at the corporate and at the personal level, to assess the impact of taxes on capital structure. Our approach has three benefits.

First, by employing panel regressions with firm- and year-fixed effects (along with other controls), we are able to provide time-series evidence that changes in taxation affect corporate capital structure. This occurs because, in a fixed-effects specification, the inclusion of firm-fixed effects removes any purely cross-sectional correlation between taxes and leverage, and identification is thus achieved off of changes in tax rates. Using this specification therefore greatly reduces the risk of a spurious result. (We later show that our conclusions are unchanged when we use different econometric methodologies, such as change regression specifications or propensity score matching.)

Second, the inclusion of personal taxes allows us to explicitly test Miller's (1977) assertion that all taxes should be considered in capital structure debates. Prior research that examines the effect of personal taxes on capital structure either focused on a single tax reform (Campello (2001), Givoly, Hahn, Ofer, and Sarig (1992), Graham (1999), and Twite (2001)) or is purely cross sectional (Booth, Aivazian, Demirgüç-Kunt, and Maksimovic (2001)). Both empirical designs are subject to potentially severe endogeneity concerns. An exception is Rajan and Zingales's (1995) study of tax reforms in the G-7 during the 1980s. However, they evaluate the combined effect of both corporate and personal taxes. In this paper, we cover the issue of personal taxes more fully and separately assess the impact of different types of taxes on capital structure choices.

Third, the use of a large and comprehensive sample of tax changes reduces the impact of noise in the data and avoids basing conclusions on any single tax reform that might have "unique" effects on corporate debt policy. In sum, our design avoids many of the empirical difficulties affecting earlier tests and provides a stronger econometric identification of the relation between taxes and capital structure choices.

We employ a variety of data sources to identify changes in the top statutory corporate tax rate and the marginal personal statutory tax rates on interest and dividend income across Organisation for Economic Co-Operation and Development (OECD) countries from 1981 to 2009. During the 561 country-years when both statutory corporate and personal tax rates (along with other controls) are available, we identify 184 changes in corporate tax rates and 298 changes in personal tax rates. We exploit those tax changes to assess the effects of taxes on capital structure.

Our results indicate that both corporate and personal taxes are significant determinants of capital structure choices. We document that firms tend to increase leverage following an increase in corporate taxes or personal taxes on dividend income, while they tend to reduce leverage following an increase in personal taxes on interest income. The magnitude of the tax effects is comparable to that of traditional capital structure determinants documented in the literature (e.g., firm size). 
For example, across all OECD countries, a 1-standard-deviation increase in corporate tax rates (635 basis points (bps)) is associated with a 252-bp increase in leverage in our sample.

While the shifts in statutory tax rates employed in this paper are "exogenous" in the sense that they do not reflect choices made at the firm level, we do recognize that the observed changes in tax rates could potentially be correlated with changes in other determinants of leverage. To mitigate this concern, in our main specifications we include firm- and year-fixed effects to control for time-invariant determinants of leverage and common macroeconomic factors. We also control for changes in bankruptcy laws, gross domestic product (GDP) growth, inflation, and real interest rates, along with all traditional determinants of leverage. We further show that the results are robust to various robustness and falsification tests.

First, we document that the effect of corporate taxes is stronger among corporate tax payers and profitable firms within a given country. The effect of personal dividend taxes is stronger among dividend payers. Furthermore, the impact of the 2003 U.S. dividend tax cut on leverage increases with the likelihood that a firm's marginal investor is an individual in a high tax bracket. Thus, within a given country, the effect of tax changes on leverage is greater among firms that we would ex ante expect to be more affected by tax considerations. It is unlikely that these subsets of firms would make greater changes to their capital structure (compared to peers) around tax reforms if an omitted factor other than tax changes was responsible for the observed changes in leverage.

Second, we address the concern that leverage might change in response to changes in corporate growth opportunities (rather than in response to changes in the tax benefits). We find that our results are present in the subsets of firms whose growth opportunities are relatively uncorrelated with changes in macroeconomic conditions, making the growth opportunity explanation of leverage changes unlikely.

Third, we show that our results are robust to controlling for various other institutional determinants of leverage such as agency considerations. We also find that tax changes have no effect on capital structure in our sample in countries in which tax evasion is high. By contrast, taxes appear to be significant determinants of capital structure choices in countries with relatively low tax evasion. Taken together, all these results suggest that it is unlikely that nontax considerations explain the documented relation between leverage and taxes.

The remainder of the paper is organized as follows: In Section II we discuss the data sources and present descriptive statistics. In Section III we present our main empirical findings. In Section IV we examine how the tax effect varies across firms depending on their tax status or the tax status of their marginal investors. In Section V we present a number of robustness tests. Section VI summarizes our empirical findings and concludes.

\section{Data and Descriptive Statistics}

\section{A. Corporate and Personal Taxes}

Through taxation, governments extract a sizeable share of the cash flows of the firms in their jurisdictions. However, most countries allow firms to deduct 
interest expenses from their taxable income. Such deductions allow firms to shield income from corporate taxation and thus, at least theoretically, increase firm value. Ceteris paribus, the incentive to use interest tax shields should increase with the level of corporate income tax rates, and we should therefore observe a positive association between corporate income tax rates and firm leverage.

On the other hand, investors who receive interest payments are often taxed at the personal level. The taxation of interest payments at the investor level can offset the benefits associated with the deductibility of interest at the corporate level (Miller (1977)). Ceteris paribus, the higher the personal tax rate on interest income, the smaller the benefits from using corporate debt. ${ }^{1}$ Thus, we expect to observe a negative association between personal tax rates on interest income and firm leverage. Similarly, dividends are typically taxed at the investor level. The higher the personal tax rate on dividend income, the greater the incentive to use corporate debt. Thus, we expect to observe a positive association between personal tax rates on dividend income and firm leverage.

We use a multitude of sources to obtain and verify tax rates. The primary data sources employed are the OECD's Tax Database ${ }^{2}$ and the World Bank's World Development Indicators. We supplement these data with news articles in various languages from Factiva; data obtained directly from the foreign tax authorities; the University of Michigan's World Tax Database; KPMG's, Deloitte's, and PricewaterhouseCoopers's tax reports; Worldwide-Tax.com; countries' official Web sites; and other country-specific data sources.

CORPORATE_TAX is the top marginal statutory corporate income tax rate in each year between (typically) 1981 and 2009. It includes both national and regional corporate income taxes. PERSONAL_INTEREST_TAX is the highest marginal tax rate applied to residents' personal interest income from corporate bonds. PERSONAL_DIVIDEND_TAX is the net top statutory tax rate on dividend income to be paid at the shareholder level. This variable takes into account reliefs and gross-up provisions available at the shareholder level in different countries. $^{3}$

We also evaluate the joint effect of corporate and personal taxes on leverage. In addition to specifications that include both corporate and personal tax changes, we also focus on a standard MILLER_TAX_INDEX (Miller (1977)), defined as $[1-(1-$ CORPORATE_TAX $) \times(1-$ PERSONAL_DIVIDEND_TAX $) /$ $(1$ - PERSONAL_INTEREST_TAX) $] .{ }^{4}$ The Miller tax index has a nice economic intuition: For a firm with a permanent amount of outstanding debt, $D$, the tax benefits associated with such debt are equal to the Miller tax index multiplied by the amount of debt outstanding. If the Miller tax index is positive, there is a greater

\footnotetext{
${ }^{1}$ This argument traces back to Farrar and Selwyn (1967) and Myers (1967).

${ }^{2}$ See http://www.oecd.org/statistics/

${ }^{3}$ As we show in Section V.D, our conclusions are unchanged if we use the average of dividends and capital gains tax rates.

${ }^{4}$ One might worry that since tax reforms often involve multiple types of taxes, the changes in different taxes may be highly correlated, giving rise to a multicollinearity problem in the regression model. However, we find that all of the correlations between the changes in corporate taxes, interest taxes, and dividend taxes are only around 0.3 , indicating that these changes are mostly uncorrelated with one another. Furthermore, we note that the Miller tax index is not subject to such a concern.
} 
incentive to use debt. If it is negative, there is a greater incentive to use equity. Ceteris paribus, firms will be indifferent between equity and debt when the Miller tax index is 0. As shown in Panel B of Table 1, the average Miller tax index across firms in our sample is 0.29 , so that the average firm has a tax incentive to use debt.

As always, a few caveats apply. First, our analysis focuses exclusively on changes in the top marginal tax rates. These tax changes would apply to all investors only in the case of a flat tax schedule. Second, tax rate changes may occur simultaneously with a change in the firm's tax base, in which case the incentives to respond would vary across firms. The complexity of these changes makes it difficult to incorporate these important details in our analysis. However, as tax cuts are typically accompanied by a broadening of the tax base (Desai, Dyck, and Zingales (2007)), these effects make it more difficult to find significant results in the direction we hypothesize.

TABLE 1

Descriptive Statistics

Panel A of Table 1 presents the sample distribution by country. Panel B presents summary statistics for the variables. Variables are defined in Section II.

Panel A. Sample Distribution by Country

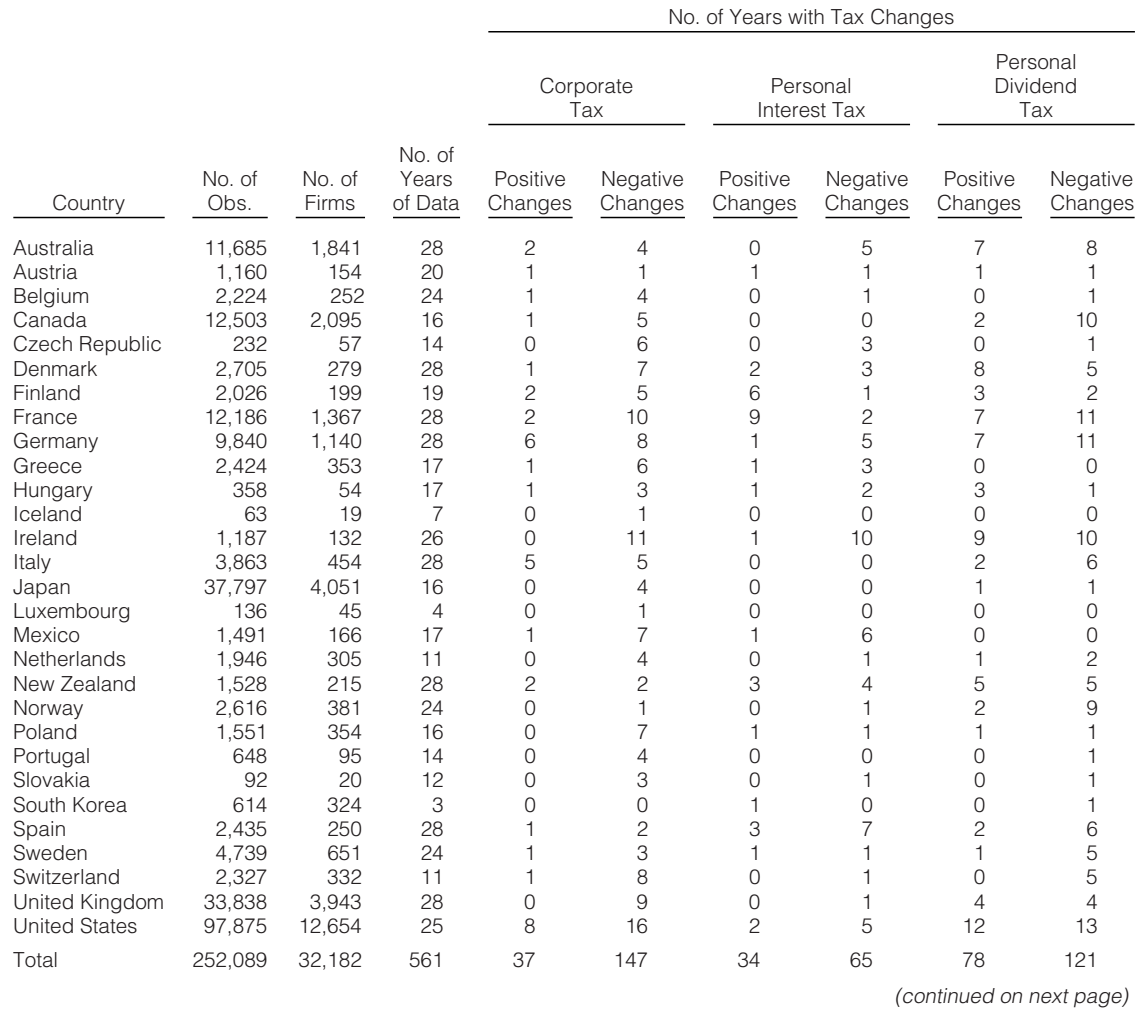


TABLE 1 (continued)

Descriptive Statistics

Panel B. Summary Statistics

\begin{tabular}{|c|c|c|c|c|c|c|}
\hline Variable & $\begin{array}{l}\text { No. of } \\
\text { Obs. }\end{array}$ & Mean & Median & $\begin{array}{l}\text { Standard } \\
\text { Deviation } \\
\end{array}$ & $\begin{array}{c}\text { 1st } \\
\text { Quartile } \\
\end{array}$ & $\begin{array}{c}\text { 3rd } \\
\text { Quartile } \\
\end{array}$ \\
\hline BOOK_LEVERAGE & 252,089 & 0.3673 & 0.3341 & 0.2960 & 0.1001 & 0.5646 \\
\hline CORPORATE_TAX & 252,089 & 0.3775 & 0.3926 & 0.0635 & 0.3399 & 0.3975 \\
\hline PERSONAL_INTEREST_TAX & 252,089 & 0.3410 & 0.3500 & 0.1017 & 0.2800 & 0.4000 \\
\hline PERSONAL_DIVIDEND_TAX & 252,089 & 0.2635 & 0.2641 & 0.1063 & 0.1814 & 0.3256 \\
\hline MILLER_TAX_INDEX & 252,089 & 0.2877 & 0.3092 & 0.1580 & 0.2023 & 0.3475 \\
\hline $\mathrm{ROA}$ & 252,089 & -0.0133 & 0.0484 & 0.4291 & -0.0014 & 0.1117 \\
\hline MB & 252,089 & 2.0159 & 1.2396 & 3.0300 & 0.9902 & 1.8385 \\
\hline TANGIBILITY & 252,089 & 0.2971 & 0.2437 & 0.2471 & 0.0889 & 0.4421 \\
\hline In(SALES) & 252,089 & 11.9040 & 12.0682 & 2.4735 & 10.5212 & 13.5345 \\
\hline R\&D/SALES & 252,089 & 0.0485 & 0.0000 & 0.1880 & 0.0000 & 0.0107 \\
\hline R\&D_NOT_MISSING_INDICATOR & 252,089 & 0.4477 & 0.0000 & 0.4973 & 0.0000 & 1.0000 \\
\hline DEPRECIATION/SALES & 252,089 & 0.0868 & 0.0394 & 0.1710 & 0.0202 & 0.0761 \\
\hline GDP_GROWTH & 252,089 & 0.0146 & 0.0192 & 0.0205 & 0.0071 & 0.0271 \\
\hline INFLATION & 252,089 & 0.0224 & 0.0227 & 0.0167 & 0.0137 & 0.0303 \\
\hline REAL_INTEREST_RATE & 252,089 & 0.0422 & 0.0388 & 0.0220 & 0.0285 & 0.0586 \\
\hline \multicolumn{7}{|l|}{ Indicators for: } \\
\hline $\begin{array}{l}\text { Above-median absolute } \\
\text { change in MB }\end{array}$ & 242,332 & 0.5229 & 1.0000 & 0.4995 & 0.0000 & 1.0000 \\
\hline $\begin{array}{l}\text { Above-median sensitivity of } \\
\text { MB change to GDP growth }\end{array}$ & 251,250 & 0.5337 & 1.0000 & 0.4989 & 0.0000 & 1.0000 \\
\hline Cyclical industry & 241,837 & 0.8178 & 1.0000 & 0.3860 & 1.0000 & 1.0000 \\
\hline Unprofitable firm & 252,089 & 0.0853 & 0.0000 & 0.2793 & 0.0000 & 0.0000 \\
\hline Non-tax payer & 251,940 & 0.0716 & 0.0000 & 0.2578 & 0.0000 & 0.0000 \\
\hline Non-dividend payer & 248,631 & 0.2876 & 0.0000 & 0.4527 & 0.0000 & 1.0000 \\
\hline
\end{tabular}

\section{B. Financial Leverage and Control Variables}

Firm-level accounting and market data come from Worldscope and Datastream. We measure leverage in book value terms. BOOK_LEVERAGE is the ratio of interest-bearing debt divided by the sum of interest-bearing debt and book value of equity.

As in Rajan and Zingales (1995), we make a number of adjustments to minimize the impact of differences in accounting standards and practices on leverage. First, we exclude firms with unconsolidated accounting statements from the analysis, as consolidation affects leverage. Second, we focus on interest-bearing debt only, as it represents the relevant measure of debt from a tax perspective. The definition of interest-bearing debt is relatively uniform across countries (with the one exception that we note later). For example, as opposed to a measure of debt that includes all liabilities, our debt measure is unaffected by differences in the accounting treatment of deferred taxes, pension liabilities, and various provisions for future liabilities, as those are not included in the definition of interest-bearing debt. Third, we control for changes in the accounting standards employed by using Worldscope to determine the accounting standards followed by each company in each year. Whenever the accounting standards employed by a firm change, we treat the post-change firm as a separate firm. ${ }^{5}$ This avoids instances in which an

\footnotetext{
${ }^{5}$ In particular, for each firm we may have multiple fixed effects, each one denoting a different set of accounting standards. We also repeat our analysis for a subsample of firms that did not change their accounting standards during our sample period, and our results are robust in this subsample.
} 
apparent change in leverage is actually the result of a change in the accounting standards employed.

Some accounting differences are nevertheless still present. A concern would arise if these accounting differences led to changes in leverage at the time of tax reforms. If that were the case, we would incorrectly attribute any change in leverage to a tax effect. Therefore, in unreported tests, we verify that our results are robust to making other adjustments proposed by Rajan and Zingales (1995). (Those adjustments cause a larger loss of observations.) First, the accounting treatment of financial leasing varies across countries. In some countries, leased assets (and corresponding liabilities) appear on the balance sheet, while in other countries firms report only annual leasing expenses in their income statement. This limits the comparability of interest-bearing debt (which includes leasing only in the countries where it appears on the balance sheet). To account for this discrepancy, we subtract financial leasing from interest-bearing debt. Second, although the definition of interest-bearing debt is relatively uniform across countries and firms, book equity is not necessarily comparable across countries and firms. In particular, deferred taxes and provisions for future liabilities should be considered as components of shareholder equity. Thus, we add them back to book equity. Third, we correct for distortions in the treatment of goodwill and intangibles (which are capitalized only in some of the countries) by subtracting the value of intangibles from the book value of equity. Our results are robust to making these adjustments in unreported tests.

We control for the standard determinants of leverage typically used in the capital structure literature. ROA is operating income divided by beginning-of-theyear total assets. MB is total assets minus book equity plus market equity, all divided by total assets. TANGIBILITY is net property, plant, and equipment divided by total assets. $\ln$ (SALES) is the logarithm of net sales or revenues (in thousands of U.S. dollars). R\&D/SALES is research and development expenses divided by net sales or revenues. When we do not have information on R\&D expenses, we replace the missing value with a 0 . To control for this censoring of the data, we add to the regressions an R\&D_NOT_MISSING_INDICATOR. This is an indicator variable that takes a value of 1 if information on $R \& D$ expenditures is available and 0 if it is missing. DEPRECIATION/SALES is depreciation divided by net sales or revenues. To minimize the impact of outliers, all firm-level variables are winsorized at the 1st and 99th percentiles.

To account for changes in bankruptcy costs, in each country we identify the first introduction of a procedure allowing an insolvent firm to undergo a Chapter 11-type court-supervised reorganization (as opposed to liquidation). ${ }^{6}$ We include a separate bankruptcy reform indicator for each country to allow each reform to have a different effect on leverage. To account for time-varying country-specific macroeconomic conditions under which firms operate, we control for (per capita) GDP_GROWTH in all regressions. Data on GDP growth are obtained from the World Bank. Finally, we control for interest rates and inflation

\footnotetext{
${ }^{6}$ We gather data on bankruptcy reforms from Armour and Cumming (2008), Fisher and Martel (2003), Galgano (1994), Korkeamäki, Koskinen, and Takalo (2007), Philippe \& Partners and Deloitte \& Touche (2002), Richter (2006), Rohrlich (1935), news articles, and Internet searches.
} 
in all specifications. The following variables are obtained from the World Bank: REAL_INTEREST_RATE is "the lending interest rate adjusted for inflation as measured by the GDP deflator," and INFLATION is measured by the Consumer Price Index and "reflects the annual percentage change in the cost to the average consumer of acquiring a basket of goods and services that may be fixed or changed at specified intervals, such as yearly."

\section{Descriptive Statistics}

The sample consists of 29 OECD countries (see Panel A of Table 1). ${ }^{7}$ The tax data cover the years 1981-2009, although some of the countries have missing information in the earlier years. ${ }^{8}$ The sample includes 252,089 firm-year observations for 32,182 firms.

Within our sample period, taxes decrease more often than they increase. During the 561 country-years in which statutory corporate or personal tax rates are available, there are 147 (37) negative (positive) changes in corporate tax rates, 65 (34) negative (positive) changes in personal taxes on interest income, and 121 (78) negative (positive) changes in personal taxes on dividends. The average corporate tax rate change is -47 bps per year, the average personal interest tax rate change is -30 bps per year, and the average personal dividend tax rate change is -99 bps per year (not reported in a table for conciseness).

The average book leverage is $37 \%$. Book leverage shows a small average increase through time. During the sample period, the mean ROA is $-1.3 \%$ and the mean market-to-book ratio is 2.02 . For the average firm, net property, plant, and equipment represent $30 \%$ of total assets. Finally, for the average firm, annual revenues are $\$ 147,855$ (thousands) $(\ln (\mathrm{SALES})=11.9)$.

\section{Empirical Results}

\section{A. Empirical Identification Strategy}

In the main tests, we identify the effect of taxes on capital structure by regressing year-end leverage on the level of tax rates at the end of the calendar year, along with firm and country control variables. We include fixed effects for each firm/accounting standard combination (henceforth "firm-fixed effects") to remove the purely cross-sectional correlation between taxes and leverage and focus on the effect of shocks to the tax rates. We also include year-fixed effects to eliminate spurious correlations arising from common macroeconomic factors in both taxes and capital structure. In all regressions, standard errors are clustered on two dimensions (Petersen (2009)): i) at the "country-year" level, to allow observations for a given country and tax reform to be correlated, and ii) at the firm level, to allow for time-series correlation.

\footnotetext{
${ }^{7}$ Turkey is excluded, as we could not find data on personal tax rates on interest income.

${ }^{8}$ For some countries, some years drop out of the sample due to missing data on personal tax rates or accounting standards. For example, information on accounting standards is not available for U.S. firms prior to 1985 .
} 


\section{B. The Effect of Corporate and Personal Taxes on Capital Structure}

We begin by examining the average effect of corporate and personal taxes on capital structure for the firms in the whole sample. Table 2 reports the regression results. BOOK_LEVERAGE is the dependent variable.

Regression 1 shows that both corporate and personal taxes have a significant effect on leverage. In particular, on average, increases in corporate taxes result in an increase in leverage, increases in personal taxes on interest income result in a decrease in leverage, and increases in personal taxes on dividend income result in an increase in leverage. These results are in line with theoretical predictions. Regression 2 considers the joint impact of taxes by focusing on the Miller tax index. Consistent with theoretical predictions, leverage increases on average following an increase in the overall (corporate and personal) tax benefits of debt. The effect of taxes is highly significant statistically, with $p$-values of less than 0.01 .

\section{TABLE 2}

Effects of Corporate and Personal Taxes on Capital Structure

\begin{tabular}{|c|c|c|}
\hline Explanatory Variables & 1 & 2 \\
\hline $\begin{array}{l}\text { Tax Variables } \\
\text { CORPORATE_TAX }\end{array}$ & $\begin{array}{l}0.397^{\star \star \star} \\
(5.51)\end{array}$ & \\
\hline PERSONAL_INTEREST_TAX & $\begin{array}{l}-0.181^{\star * *} \\
(-3.87)\end{array}$ & \\
\hline PERSONAL_DIVIDEND_TAX & $\begin{array}{l}0.139^{\star \star \star} \\
(4.12)\end{array}$ & \\
\hline MILLER_TAX_INDEX & & $\begin{array}{l}0.201^{\star \star \star} \\
(5.77)\end{array}$ \\
\hline $\begin{array}{l}\text { Control Variables } \\
\text { ROA }\end{array}$ & $\begin{array}{l}-0.058^{\text {*** }} \\
(-6.87)\end{array}$ & $\begin{array}{l}-0.058^{\star \star \star} \\
(-6.85)\end{array}$ \\
\hline MB & $\begin{array}{l}0.006^{\star \star *} \\
(5.74)\end{array}$ & $\begin{array}{l}0.006^{\star \star \star} \\
(5.69)\end{array}$ \\
\hline TANGIBILITY & $\begin{array}{l}0.219^{\star \star *} \\
(16.31)\end{array}$ & $\begin{array}{l}0.216^{\star \star \star \star} \\
(15.88)\end{array}$ \\
\hline In(SALES) & $\begin{array}{l}0.023^{\star \star *} \\
(7.79)\end{array}$ & $\begin{array}{l}0.024^{\star \star} \\
(7.83)\end{array}$ \\
\hline R\&D/SALES & $\begin{array}{l}-0.024^{\star \star} \\
(-2.00)\end{array}$ & $\begin{array}{l}-0.023^{*} \\
(-1.93)\end{array}$ \\
\hline R\&D_NOT_MISSING_INDICATOR & $\begin{array}{r}0.001 \\
(0.36)\end{array}$ & $\begin{array}{l}-0.000 \\
(-0.11)\end{array}$ \\
\hline DEPRECIATION/SALES & $\begin{array}{l}0.048^{\star \star \star} \\
(3.34)\end{array}$ & $\begin{array}{l}0.048^{\star \star \star} \\
(3.36)\end{array}$ \\
\hline GDP_GROWTH & 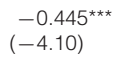 & $\begin{array}{l}-0.498^{\star \star \star} \\
(-4.26)\end{array}$ \\
\hline INFLATION & $\begin{array}{l}0.134 \\
(0.91)\end{array}$ & $\begin{array}{l}0.205 \\
(1.31)\end{array}$ \\
\hline REAL_INTEREST_RATE & $\begin{array}{l}-0.153^{*} \\
(-1.75)\end{array}$ & $\begin{array}{l}-0.217^{* *} \\
(-2.21)\end{array}$ \\
\hline $\begin{array}{l}\text { Bankruptcy reform dummies } \\
\text { Firm-fixed effects } \\
\text { Year-fixed effects }\end{array}$ & $\begin{array}{l}\text { Yes } \\
\text { Yes } \\
\text { Yes }\end{array}$ & $\begin{array}{l}\text { Yes } \\
\text { Yes } \\
\text { Yes }\end{array}$ \\
\hline $\begin{array}{l}\text { No. of obs. } \\
\text { Adj. } R^{2}\end{array}$ & $\begin{array}{c}252,089 \\
0.70\end{array}$ & $\begin{array}{c}252,089 \\
0.71\end{array}$ \\
\hline
\end{tabular}


We assess the economic significance of taxes on capital structure in our sample using three metrics based on ex post observed summary statistics. First, we use an elasticity measure. Elasticity is the percent increase in the dependent variable due to a $1 \%$ increase in a given independent variable. Thus, elasticity is computed as $(d y / d x) \times(x / y)$, where $(d y / d x)$ is the regression coefficient for the independent variable under consideration. We evaluate elasticities at the mean values of $x$ and $y$. We compute elasticities based on the coefficient estimates in regressions 1 and 2 of Table 2.

Columns 1 and 2 of Table 3 report the elasticities. Based on this metric, taxes appear to be economically important determinants of capital structure choices. As shown in column 1 , a $1 \%$ increase in corporate tax rates produces a $0.41 \%$ increase in leverage in our sample. Personal taxes also appear to be important in our sample, although less so than corporate taxes. On average, a $1 \%$ increase in the personal tax rate on interest income results in a $0.17 \%$ decline in leverage, while a $1 \%$ increase in the personal tax rate on dividends in our sample results in a $0.10 \%$ increase in leverage. The elasticity of leverage to changes in the control variables is generally small when compared to similar percentage changes in the tax variables. The only variable that appears to be more economically important than taxes is firm size (measured by $\ln ($ SALES)).

As a second approach, we use standard deviations to assess the economic impact of tax changes on leverage in our sample. In particular, we measure the impact of a 1-standard-deviation change in tax rates on leverage. (We then compare this to the standard deviation (STDEV) of leverage.) Thus, our second measure of

\section{TABLE 3}

\section{Economic Significance}

\begin{tabular}{|c|c|c|c|c|c|c|}
\hline \multirow[b]{5}{*}{ Explanatory Variables } & 1 & 2 & 3 & 4 & 5 & 6 \\
\hline & \multicolumn{6}{|c|}{ Elasticity } \\
\hline & \multicolumn{2}{|c|}{$(d y / d x) \times(x / y)$} & \multirow{2}{*}{\multicolumn{2}{|c|}{$\frac{(d y / d x) \times \operatorname{STDEV}(x)}{\text { Regression Model }}$}} & \multicolumn{2}{|c|}{$(d y / d x) \times \operatorname{IQR}(x)$} \\
\hline & & & & & & \\
\hline & 1 & 2 & 1 & 2 & 1 & 2 \\
\hline $\begin{array}{l}\text { Tax Variables } \\
\text { CORPORATE_TAX } \\
\text { PERSONAL_INTEREST_TAX } \\
\text { PERSONAL_DIVIDEND_TAX } \\
\text { MILLER_TAX_INDEX }\end{array}$ & $\begin{array}{r}0.41 \\
-0.17 \\
0.10\end{array}$ & 0.16 & $\begin{array}{r}252 \\
-184 \\
148\end{array}$ & 318 & $\begin{array}{r}229 \\
-217 \\
200\end{array}$ & 292 \\
\hline $\begin{array}{l}\text { Control Variables } \\
\text { ROA } \\
\text { MB } \\
\text { TANGIBILITY } \\
\text { In(SALES) } \\
\text { R\&D/SALES } \\
\text { R\&D_NOT_MISSING_INDICATOR } \\
\text { DEPRECIATION/SALES } \\
\text { GDP_GROWTH } \\
\text { INFLATION } \\
\text { REAL_INTEREST_RATE }\end{array}$ & $\begin{array}{c}0.002 \\
0.03 \\
0.18 \\
0.75 \\
-0.003 \\
0.001 \\
0.01 \\
-0.02 \\
0.01 \\
-0.02\end{array}$ & $\begin{array}{c}0.002 \\
0.03 \\
0.17 \\
0.78 \\
-0.003 \\
0.000 \\
0.01 \\
-0.02 \\
0.01 \\
-0.01\end{array}$ & $\begin{array}{r}-249 \\
182 \\
541 \\
569 \\
-45 \\
5 \\
82 \\
-82 \\
17 \\
-44\end{array}$ & $\begin{array}{r}-249 \\
182 \\
534 \\
594 \\
-43 \\
0 \\
82 \\
-103 \\
33 \\
-44\end{array}$ & $\begin{array}{r}-66 \\
51 \\
774 \\
693 \\
-3 \\
10 \\
27 \\
-89 \\
22 \\
-46\end{array}$ & $\begin{array}{r}-66 \\
51 \\
763 \\
723 \\
-2 \\
0 \\
27 \\
-99 \\
34 \\
-65\end{array}$ \\
\hline
\end{tabular}


economic impact is defined as $(d y / d x) \times \operatorname{STDEV}(x)$, where $(d y / d x)$ is again the regression coefficient for the independent variable under consideration.

The results are shown in columns 3 and 4 of Table 3. As the top row of column 3 shows, a 1-standard-deviation increase in corporate tax rate $(635 \mathrm{bps})$ moves leverage by 252 bps, or 0.09 standard deviations, in our sample. Similarly, a 1-standard-deviation increase in the personal tax rate on interest income ( $1,017 \mathrm{bps})$ moves leverage by $184 \mathrm{bps}$, or 0.06 standard deviations. Additionally, a 1-standard-deviation increase in the Miller tax index increases leverage by 318 bps, or 0.11 standard deviations. In comparison, other country factors have much lower economic impacts on leverage: A 1-standard-deviation change in GDP growth, inflation, or real interest rates corresponds to a change in leverage of less than 100 bps. Only tangibility and firm size display an economic impact on leverage greater than that of taxes. The large impact of tangibility on leverage echoes the results in Campello and Giambona (2013).

As a third approach, we use interquartile ranges (IQRs) to assess the economic impact of tax changes on leverage. More specifically, we measure the impact of a change in each independent variable from the first to the third quartile of its distribution. Thus, our third measure of economic impact is defined as $(d y / d x) \times \operatorname{IQR}(x)$, where $(d y / d x)$ is the regression coefficient for the independent variable under consideration.

The results are shown in columns 5 and 6 of Table 3 . As reported in the top row of column 5 , an increase in the corporate tax rate from the first to the third quartile (576 bps) moves leverage by 229 bps. Similarly, an increase in the personal tax rate on interest income from the first to the third quartile (1,200 bps) moves leverage by 217 bps. An increase in the personal tax rate on dividend income from the first to the third quartile (1,442 bps) increases leverage by 200 bps. Additionally, an increase in the Miller tax index from the first to the third quartile (1,452 bps) increases leverage by 292 bps. Again, only tangibility and firm size display an economic impact on leverage greater than that of taxes.

\section{Top Tax Payers}

Tax law changes may have heterogeneous effects on firms, depending on the applicable marginal tax rate. For example, when using top personal tax rates, Rajan and Zingales (1995) show that firms respond to changes in the tax treatment of debt and equity by shifting the allocation of pretax dollars toward the route that benefits the most from the reform. However, they document that this result does not hold when the tax rates applicable to an "average citizen" are considered. They therefore argue that it is important to consider the appropriate tax rate. With this in mind, in this section we exploit differences in firm and investor characteristics to isolate those firms that should be most likely to respond to a given tax change. Evidence that the firms that should respond more to tax changes do, in fact, do so further strengthens our interpretation that taxes affect capital structure.

\section{A. Profitable Firms and Firms with Positive Tax Outlays}

The importance of corporate taxes depends crucially on firms' profitability and on various tax shield strategies employed. In particular, profitable firms are 
more likely to incur tax liabilities. Therefore, the top marginal statutory corporate tax rates are more relevant for these firms than for unprofitable firms. To address the issue of whether the leverage of more profitable firms is more sensitive to changes in corporate tax rates, we interact the change in corporate tax rates with an indicator denoting firms that reported negative or 0 earnings in at least half of their sample years (unprofitable firms). ${ }^{9}$ We compare these firms to the remaining firms. As regression 1 in Panel A of Table 4 shows, profitable firms adjust their leverage following tax changes to a greater degree than unprofitable firms.

\title{
TABLE 4
}

Top Tax Payers, Marginal Investors, and the Effects of Taxes on Capital Structure

\begin{abstract}
In Panel A of Table 4, UNPROFITABLE_FIRM is an indicator that takes the value of 1 if the firm reported negative or 0 earnings during at least half of its sample years, and 0 otherwise. NON-TAX_PAYER is an indicator that takes the value of 1 if the firm did not pay taxes during at least half of its sample years, and 0 otherwise. NON-DIVIDEND_PAYER is an indicator that takes the value of 1 if the firm paid no dividends during 1981-2009, and 0 otherwise. The regressions include the same control variables as Table 2 (not reported for space reasons). The $t$-statistics based on standard errors adjusted for two-way clustering (i.e., country-year cells and firm) are shown in parentheses below the coefficien estimates. Panel B uses U.S. data only. In Panel B, the dependent variable is the change in leverage during 2003. DIVIDEND_PAYER is an indicator that takes the value of 1 if the firm paid cash dividends at least once during 19812009, and 0 otherwise. Cumulative Stock Return Around the 2003 Tax Reform is the cumulative stock return during the eight event windows identified in Auerbach and Hassett (2007). INSTITUTIONAL_OWNERSHIP is the aggregate ownership fraction by all institutional shareholders of a firm at the beginning of 2003. The regression in column 1 uses data from Worldscope and the regression in column 2 uses data from Compustat. The regressions include all firm control variables as in Table 2 (not reported for space reasons). All variables are the year-on-year changes of their corresponding level variables. The $t$-statistics are shown in parentheses below the coefficient estimates; ${ }^{* *},{ }^{* *}$, and * indicate significance at the $1 \%, 5 \%$, and $10 \%$ levels, respectively.
\end{abstract}

Panel A. Top Tax Payers

\begin{tabular}{l} 
Explanatory Variables \\
\hline CORPORATE_TAX \\
PERSONAL_INTEREST_TAX \\
PERSONAL_DIVIDEND_TAX \\
CORPORATE_TAX \\
$\quad \times$ UNPROFITABLE_FIRM \\
CORPORATE_TAX \\
$\quad \times$ NON-TAX_PAYER \\
PERSONAL_DIVIDEND_TAX \\
$\times$ NON-DIVIDEND_PAYER
\end{tabular}

$\frac{1}{0.515^{\star \star \star}}$
$(7.25)$
$-0.186^{\star \star}$
$(-4.13)$
$0.133^{\star \star \star}$
$(4.11)$
$-0.778^{\star \star \star}$
$(-7.37)$

$\begin{array}{cc}2 & \frac{3}{2} \\ 0.467^{\star \star \star} & 0.354^{\star \star \star} \\ (6.57) & (5.15) \\ -0.186^{\star \star} & -0.134^{\star \star \star} \\ (-4.05) & (-3.00) \\ 0.134^{\star \star \star} & 0.145^{\star \star \star} \\ (4.05) & (4.30)\end{array}$

Control variables

Bankruptcy reform dummies

Firm-fixed effects

Year-fixed effects

No. of obs.

Adj. $R^{2}$

$(-7.37)$

$\begin{array}{ccc} & (-5.37) & \\ & & -0.285^{\star \star \star} \\ \text { Yes } & & (-5.32) \\ \text { Yes } & \text { Yes } & \text { Yes } \\ \text { Yes } & \text { Yes } & \text { Yes } \\ \text { Yes } & \text { Yes } & \text { Yes } \\ 252,089 & \text { Yes } & \text { Yes } \\ 0.70 & 252,089 & 248,631 \\ & 0.70 & 0.70\end{array}$

Panel B. Leverage Adjustment around the 2003 U.S. Tax Reform

\section{Explanatory Variables}

Dividend payer indicator

Likelihood that the marginal investor is an individual:

Cumulative stock return around the 2003 tax reform

Likelihood that the marginal investor is an individual:

(1 - INSTITUTIONAL_OWNERSHIP)

Control variables

No. of obs.

Adj. $R^{2}$

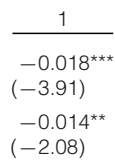

$$
\frac{2}{-0.037^{\text {ᄎᄎ }}}
$$$$
(-2.08)
$$

$-0.025^{\star \star}$

$(-2.40)$

Yes

1,690

0.05

\footnotetext{
${ }^{9}$ We do not include the individual components of our interactions, since they are absorbed by the firm-fixed effects.
} 
As a related test, we alternatively compare firms that did not pay taxes during at least half of their sample years with the remaining firms. We expect the impact of corporate tax changes on leverage to be weaker for those firms that do not often pay taxes. The results in regression 2 of Table 4 indicate that this is the case.

\section{B. Dividend versus Non-Dividend Payers}

If dividend policy is fixed and to the extent that dividend taxes affect the relative costs of debt and equity, the effect of dividend taxes on leverage should be weaker for firms that do not pay dividends. In non-dividend-paying firms, the dividend tax should not affect the cash flow to shareholders and therefore should not affect firm value. We examine this prediction by identifying a subgroup of firms that paid no dividends during the sample period. About $29 \%$ of firms fall into this subgroup. We expect a less positive coefficient on the PERSONAL_DIVIDEND_TAX variable for firms that paid no dividends. To assess whether this is the case, we add an interaction term between the personal dividend tax variable and an indicator identifying firms that paid no dividends (NON-DIVIDEND_PAYER) to our specifications. The results are shown in regression 3 of Panel A of Table 4. We expect a negative sign on the coefficient of the interaction term. Consistent with our prediction, we find a significantly negative coefficient for the interaction term. Thus, for firms that paid no dividends, dividend tax reforms appear to have less of an impact on capital structure decisions.

\section{The Identity of the Marginal Investor}

We next attempt to infer the likelihood that the marginal investor in firms is an individual in a high tax bracket. Personal dividend taxes should matter more when this is the case. For this purpose, we focus on an unanticipated tax reform to draw inferences on the marginal investor's type. Our approach is similar to that of Brown, Liang, and Weisbenner (2007), who examine the stock price response to the 2003 dividend tax cut. As they point out, the stock price response to the dividend tax cut is expected to be larger for firms with higher individual ownership, as individuals are the only group of investors that gains from the reduction in personal tax rates. In other words, the stock price response to the dividend tax cut should depend on the identity of the marginal investor.

For our purposes, we also focus on the 2003 dividend tax cut in the United States, as Brown et al. (2007) indicate that this reform is largely unanticipated. This allows for a clean test of our tax story based on cumulative stock returns. We compute the cumulative stock price return during the eight event windows identified by Auerbach and Hassett (2007). These windows span from the first announcement of the tax cut proposal by the White House to the final passage of the reform. ${ }^{10}$ We use the cumulative stock price return during the eight event

\footnotetext{
${ }^{10}$ These eight event windows capture various incremental announcements and account for the release of information over time.
} 
windows as a proxy for the likelihood that the marginal investor is an individual in a high tax bracket. To the extent that the cumulative stock price return is a valid proxy for the likelihood that the marginal investor is an individual in a high tax bracket, we should find that firms experiencing a more positive stock price increase around the 2003 dividend tax reform will be more likely to reduce leverage. This claim is based on two presumptions. First, as dividends are taxed at the investor level, lower personal tax rates on dividends correspond to lower incentives to use corporate debt. Second, the reduction in leverage should be confined to companies whose marginal investor is an individual, as the reform affected the taxation only of individual investors. The results in the first regression in Panel B of Table 4 are consistent with our prediction: The change in leverage during 2003 is negatively and significantly associated with the likelihood that the marginal investor is an individual.

Our second approach to identify firms that are more likely to have an individual as the marginal investor relies on the hypothesis that as the ownership by a certain investor group increases (e.g., tax-exempt institutions), so does the likelihood that this investor group is the marginal investor. Several authors have made such a claim (Ayers, Cloyd, and Robinson (2002), Bell and Jenkinson (2002), Dhaliwal, Krull, and Li (2007), and Dhaliwal, Krull, Li, and Moser (2005)). For example, if all stocks were held by tax-exempt institutions, the marginal investor would be a tax-exempt institution.

We do not generally have information on the identity of investors by type and tax bracket. However, some data from Thomson Reuters are available for U.S. firms on the aggregate ownership by institutional investors (which include many tax-exempt institutions). We again use the 2003 dividend tax cut as an event that others have argued to be exogenous and unanticipated. As government ownership was not prevalent in the United States in 2003, we assume that the ownership by individual investors can be measured as (1-institutional ownership). A further assumption of our calculation is that corporations do not hold other firms' ordinary shares. To the extent that this variable is a valid proxy for the likelihood that the marginal investor is an individual, we should find that firms with greater ownership by individual investors will be more likely to reduce leverage. Regression 2 in Panel B of Table 4 is consistent with this prediction.

Thus, it appears that the leverage changes observed around the 2003 reform in the United States are especially pronounced when the marginal investor is more likely to be an individual (and thus more likely to be affected by the tax changes introduced). These results further support the notion that our prior results are unlikely to be spurious.

\section{Robustness Tests}

\section{A. Change Regression Specifications}

In the earlier analyses, we employed level regression specifications to identify the effect of taxes on capital structure. In the level specifications, leverage was regressed on firm control variables and tax rates. We included firm-fixed effects 
to remove the purely cross-sectional correlation between taxes and leverage and focus on the time-series effect.

For robustness purposes, in this section we employ change regression specifications. The change regression specifications, which focus on year-to-year changes in financial leverage, are useful for explaining incremental decisions made during a given period (MacKie-Mason (1990)). ${ }^{11}$ However, to the extent that firms adjust their capital structure slowly (Fama and French (2012), Öztekin and Flannery (2012)), the change specifications will underestimate the true impact of tax changes on capital structure choices. We therefore assess whether there is any incremental effect of tax changes on capital structure up to 2 years after a tax reform. The results are reported in Table 5.

We continue to find a statistically significant impact of tax reforms on leverage in the years following a tax reform using these specifications. Importantly, these results corroborate a tax effect on capital structure decisions, while confirming that the adjustment takes some time.

TABLE 5

Effects of Taxes on Capital Structure: Change Regression Specifications

\begin{tabular}{|c|c|c|c|c|}
\hline Explanatory Variables & 1 & 2 & 3 & 4 \\
\hline $\begin{array}{l}\text { Annual Changes in Tax Variables } \\
\text { CORPORATE_TAX }\end{array}$ & $\begin{array}{l}0.137^{* *} \\
(2.11)\end{array}$ & $\begin{array}{l}0.113^{*} \\
(1.74)\end{array}$ & & \\
\hline CORPORATE_TAX, 1 year lagged & & $\begin{array}{r}0.100 \\
(1.63)\end{array}$ & & \\
\hline CORPORATE_TAX, 2 years lagged & & $\begin{array}{l}0.122^{* *} \\
(2.52)\end{array}$ & & \\
\hline PERSONAL_INTEREST_TAX & $\begin{array}{c}0.002 \\
(0.10)\end{array}$ & $\begin{array}{c}0.009 \\
(0.38)\end{array}$ & & \\
\hline PERSONAL_INTEREST_TAX, 1 year lagged & & $\begin{array}{l}-0.078^{\star \star \star} \\
(-2.62)\end{array}$ & & \\
\hline PERSONAL_INTEREST_TAX, 2 years lagged & & $\begin{array}{l}-0.026 \\
(-1.24)\end{array}$ & & \\
\hline PERSONAL_DIVIDEND_TAX & $\begin{array}{l}0.020^{*} \\
(1.92)\end{array}$ & $\begin{array}{l}0.019^{* *} \\
(2.05)\end{array}$ & & \\
\hline PERSONAL_DIVIDEND_TAX, 1 year lagged & & $\begin{array}{l}0.027^{*} \\
(1.95)\end{array}$ & & \\
\hline PERSONAL_DIVIDEND_TAX, 2 years lagged & & $\begin{array}{l}0.013 \\
(0.84)\end{array}$ & & \\
\hline MILLER_TAX_INDEX & & & $\begin{array}{l}0.030^{\star} \\
(1.77)\end{array}$ & $\begin{array}{l}0.025 \\
(1.53)\end{array}$ \\
\hline MILLER_TAX_INDEX, 1 year lagged & & & & $\begin{array}{l}0.042^{\star \star \star} \\
(2.70)\end{array}$ \\
\hline MILLER_TAX_INDEX, 2 years lagged & & & & $\begin{array}{l}0.032^{\star \star} \\
(2.38)\end{array}$ \\
\hline
\end{tabular}

(continued on next page)

\footnotetext{
${ }^{11}$ Many authors have used an incremental approach to study corporate decisions. Examples include MacKie-Mason (1990) and Hovakimian, Opler, and Titman (2001) on the debt-equity choice; Jung, Kim, and Stulz (1995) on the external financing decision; and Denis and Mihov (2003) on the borrowing decision.
} 
TABLE 5 (continued)

Effects of Taxes on Capital Structure: Change Regression Specifications

\begin{tabular}{|c|c|c|c|c|}
\hline Explanatory Variables & 1 & 2 & 3 & 4 \\
\hline $\begin{array}{l}\text { Annual Changes in Control Variables } \\
\text { ROA }\end{array}$ & $\begin{array}{l}-0.023^{\star \star \star} \\
(-4.72)\end{array}$ & $\begin{array}{l}-0.026^{\star \star \star} \\
(-4.76)\end{array}$ & $\begin{array}{l}-0.023^{\star \star \star} \\
(-4.72)\end{array}$ & $\begin{array}{l}-0.026^{\star \star \star} \\
(-4.74)\end{array}$ \\
\hline MB & $\begin{array}{l}0.004^{\star \star \star} \\
(7.10)\end{array}$ & $\begin{array}{l}0.004^{\star \star \star} \\
(6.35)\end{array}$ & $\begin{array}{l}0.004^{\star \star *} \\
(7.06)\end{array}$ & $\begin{array}{l}0.004^{\star \star \star} \\
(6.31)\end{array}$ \\
\hline TANGIBILITY & $\begin{array}{l}0.267^{\star \star \star} \\
(20.82)\end{array}$ & $\begin{array}{l}0.255^{\star \star \star} \\
(21.19)\end{array}$ & $\begin{array}{l}0.267^{\star \star \star} \\
(20.75)\end{array}$ & $\begin{array}{l}0.255^{\star \star \star} \\
(21.06)\end{array}$ \\
\hline In(SALES) & $\begin{array}{l}0.021^{\star \star \star} \\
(8.15)\end{array}$ & $\begin{array}{l}0.020^{* * *} \\
(7.38)\end{array}$ & $\begin{array}{l}0.021^{* * *} \\
(8.21)\end{array}$ & $\begin{array}{l}0.020^{\star \star \star} \\
(7.35)\end{array}$ \\
\hline R\&D/SALES & $\begin{array}{l}-0.021^{*} \\
(-1.68)\end{array}$ & $\begin{array}{l}-0.019 \\
(-1.37)\end{array}$ & $\begin{array}{l}-0.021^{\star} \\
(-1.66)\end{array}$ & $\begin{array}{l}-0.019 \\
(-1.38)\end{array}$ \\
\hline R\&D_NOT_MISSING_INDICATOR & $\begin{array}{r}-0.001 \\
(-0.74)\end{array}$ & $\begin{array}{l}-0.000 \\
(-0.25)\end{array}$ & $\begin{array}{l}-0.001 \\
(-0.54)\end{array}$ & $\begin{array}{l}0.000 \\
(0.04)\end{array}$ \\
\hline DEPRECIATION/SALES & $\begin{array}{l}0.100^{* * *} \\
(6.99)\end{array}$ & $\begin{array}{l}0.093^{\star \star *} \\
(6.21)\end{array}$ & $\begin{array}{l}0.100^{* * *} \\
(7.01)\end{array}$ & $\begin{array}{l}0.093^{\star \star \star} \\
(6.18)\end{array}$ \\
\hline GDP_GROWTH & $\begin{array}{l}-0.063 \\
(-0.54)\end{array}$ & $\begin{array}{l}-0.041 \\
(-0.43)\end{array}$ & $\begin{array}{l}-0.079 \\
(-0.68)\end{array}$ & $\begin{array}{l}-0.059 \\
(-0.60)\end{array}$ \\
\hline INFLATION & $\begin{array}{l}0.023 \\
(0.23)\end{array}$ & $\begin{array}{l}0.008 \\
(0.08)\end{array}$ & $\begin{array}{l}0.025 \\
(0.24)\end{array}$ & $\begin{array}{l}0.019 \\
(0.19)\end{array}$ \\
\hline REAL_INTEREST_RATE & $\begin{array}{l}-0.071 \\
(-1.29)\end{array}$ & $\begin{array}{l}-0.094^{*} \\
(-1.73)\end{array}$ & $\begin{array}{l}-0.077 \\
(-1.40)\end{array}$ & $\begin{array}{l}-0.101^{*} \\
(-1.82)\end{array}$ \\
\hline $\begin{array}{l}\text { Bankruptcy reform dummies } \\
\text { Year-fixed effects }\end{array}$ & $\begin{array}{l}\text { Yes } \\
\text { Yes }\end{array}$ & $\begin{array}{l}\text { Yes } \\
\text { Yes }\end{array}$ & $\begin{array}{l}\text { Yes } \\
\text { Yes }\end{array}$ & $\begin{array}{l}\text { Yes } \\
\text { Yes }\end{array}$ \\
\hline $\begin{array}{l}\text { No. of obs. } \\
\text { Adj. } R^{2}\end{array}$ & $\begin{array}{c}210,843 \\
0.03\end{array}$ & $\begin{array}{c}192,142 \\
0.03\end{array}$ & $\begin{array}{c}210,843 \\
0.03\end{array}$ & $\begin{array}{c}192,142 \\
0.03\end{array}$ \\
\hline
\end{tabular}

\section{B. Propensity Score Matching}

For robustness purposes, we also employ a propensity score matching procedure (Rosenbaum and Rubin (1983)). This procedure identifies a control sample of firms that do not undergo a tax reform but are otherwise similar in characteristics to the firms experiencing a tax reform. Once these matching peers are identified, we can compare the change in leverage (relative to year-end leverage in the year before the tax reform) between the two groups. Since the control firms are restricted to a set of peers that are nearly identical in terms of observable characteristics, leverage changes should be similar between the two sets of firms if tax changes do not affect leverage choices.

To implement this methodology, we first calculate the propensity (score) that a firm with given characteristics experiences a tax reform in a given year. For the purpose of this test, we focus on "large" reforms. In particular, we focus on reforms that result in changes in the Miller tax index of at least 5 percentage points. We focus on the Miller tax index (as opposed to individual tax variables) because many of the tax reforms alter different tax rates at the same time. This dynamic makes changes in the Miller tax index, which reflect the joint change in corporate and personal tax rates, more suitable for a difference-in-difference analysis.

This propensity score is estimated as a function of firm characteristics (ROA, $\mathrm{MB}$, tangibility, $\ln$ (sales), R\&D/sales, the "R\&D not missing indicator," and depreciation/sales) and country-level variables (GDP growth, inflation, and the real interest rate). Reform firms and matching peers are selected from the same year. 
To minimize differences between the two sets of firms, we require that the maximum difference between the propensity scores does not exceed $0.01 \%$ in absolute value. $^{12}$

In Panel A of Table 6, we compare the change in book leverage for firms in countries experiencing a tax reform to that of control firms from countries without a tax reform. The change in leverage is measured relative to the year-end prior to the tax reform. We report the change in leverage during the year of the reform as well as the cumulative change in leverage as of 1,2, and 3 years after the tax reform. The results in Table 6 indicate that even when matching on observable firm characteristics and country-level variables (see Panel B of Table 6), firms experiencing a large reduction in the Miller tax index reduce leverage significantly more than firms that do not experience a tax reform. Similarly, firms experiencing a large increase in the Miller tax index increase leverage significantly more than their nonreform peers. The results by year also show that although leverage decreases quickly following tax cuts, it increases relatively slowly after tax increases. Overall, these results support the notion that the documented changes in

\section{TABLE 6}

\section{Capital Structure Changes after Tax Reforms: Propensity Score Matching Results}

A tax reform is defined as a change in the Miller tax index of at least 5 percentage points in absolute value. The control firms are matched by country variables including GDP_GROWTH, INFLATION, and the REAL_INTEREST_RATE, and firm characteristics including ROA, MB, TANGIBILITY, In(SALES), R\&D/SALES, the "R\&D_NOT_MISSING_INDICATOR," and DEPRECIATION/SALES. The matching process follows the propensity score matching procedure proposed by Rosenbaum and Rubin (1983). The $p$-values are based on two-tailed $t$-tests. Panel A reports the average change in book leverage in the tax reform and matching samples, as well as the difference between the two. Results are reported separately for taxreducing and tax-increasing reforms. Panel $\mathrm{B}$ compares the firm and country characteristics between the tax reform and the matching samples.

Panel A. Average Cumulative Change in Book Leverage Relative to Year-End Leverage in the Year Before the Tax Reform

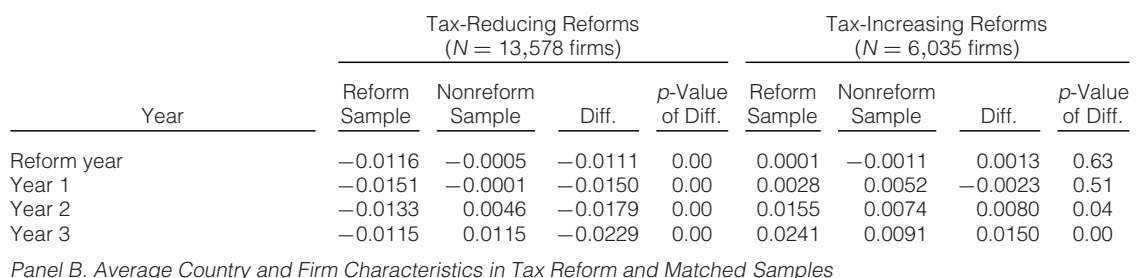

Panel B. Average Country and Firm Characteristics in Tax Reform and Matched Samples

\begin{tabular}{|c|c|c|c|c|c|c|c|c|}
\hline \multirow[b]{2}{*}{ Variables } & \multicolumn{4}{|c|}{ Tax-Reducing Reforms } & \multicolumn{4}{|c|}{ Tax-Increasing Reforms } \\
\hline & $\begin{array}{l}\text { Reform } \\
\text { Sample } \\
\end{array}$ & $\begin{array}{c}\text { Nonreform } \\
\text { Sample } \\
\end{array}$ & Diff. & $\begin{array}{c}p \text {-Value } \\
\text { of Diff. } \\
\end{array}$ & $\begin{array}{l}\text { Reform } \\
\text { Sample } \\
\end{array}$ & $\begin{array}{c}\text { Nonreform } \\
\text { Sample } \\
\end{array}$ & Diff. & $\begin{array}{c}p \text {-Value } \\
\text { of Diff. }\end{array}$ \\
\hline $\mathrm{ROA}$ & 0.0105 & 0.0047 & 0.0057 & 0.22 & 0.0704 & 0.0763 & -0.0059 & 0.07 \\
\hline $\mathrm{MB}$ & 2.0777 & 2.0742 & 0.0035 & 0.92 & 1.6430 & 1.6237 & 0.0193 & 0.49 \\
\hline TANGIBILITY & 0.3119 & 0.3076 & 0.0042 & 0.14 & 0.3283 & 0.3262 & 0.0021 & 0.63 \\
\hline $\ln ($ SALES) & 12.1876 & 12.2536 & -0.0659 & 0.02 & 12.0527 & 11.9052 & 0.1474 & 0.00 \\
\hline R\&D/SALES & 0.0494 & 0.0486 & 0.0008 & 0.74 & 0.0191 & 0.0163 & 0.0028 & 0.07 \\
\hline R\&D_NOT_MISSING_INDICATOR & 0.5040 & 0.5060 & -0.0021 & 0.73 & 0.3773 & 0.3786 & -0.0013 & 0.88 \\
\hline DEPRECIATION/SALES & 0.0820 & 0.0793 & 0.0027 & 0.15 & 0.0589 & 0.0583 & 0.0006 & 0.73 \\
\hline GDP_GROWTH & 0.0199 & 0.0193 & 0.0005 & 0.00 & 0.0209 & 0.0206 & 0.0003 & 0.23 \\
\hline INFLATION & 0.0206 & 0.0202 & 0.0003 & 0.10 & 0.0270 & 0.0267 & 0.0003 & 0.30 \\
\hline REAL_INTEREST_RATE & 0.0375 & 0.0378 & -0.0003 & 0.24 & 0.0432 & 0.0436 & -0.0004 & 0.34 \\
\hline
\end{tabular}

\footnotetext{
${ }^{12}$ As presented in Panel B of Table 6, the methodology appears to match relatively well in terms of firm characteristics and country-level variables. Although the differences in some country and firm characteristic variables are statistically significant, they are relatively small in magnitude.
} 
leverage following tax reforms are unlikely to be due to differences in observed firm or country characteristics.

\section{Macroeconomic Conditions}

A concern with our earlier analysis is that tax changes might occur in response to (or coincide with) shifts in local macroeconomic conditions that by themselves would generate leverage changes. For example, if tax rates are reduced to stimulate growth, firms might delever in response to better growth opportunities rather than in response to tax incentives. To address whether this is the case, we investigate whether tax changes tend to coincide with particular macroeconomic conditions. We find that, to some extent, this appears to be the case. Countries appear to reduce taxes when the economy is doing relatively poorly, while tax rates are more likely to increase when the economy is doing relatively well. Additionally, we find that GDP growth slows after a tax rate increase (and so does firm performance), while GDP growth and firm performance improve after tax rate reductions. ${ }^{13}$

To the extent that changing conditions affect individual firms differently, it may not be sufficient to simply control for these effects as we did in our previous analyses. To address this concern, we identify subsets of firms whose growth opportunities are "uncorrelated" with the business cycle. Since these firms' opportunities are relatively less affected by macroeconomic factors, any leverage changes are likely driven by tax benefits rather than the economic implications of the tax changes. We present two sets of tests.

First, we identify as "high growth" firms from industries whose MB ratio is more sensitive to changes in macroeconomic conditions (in particular, GDP growth). To do so, we run industry-by-industry regressions of the annual change in MB on GDP growth (we require at least 12 years of observations for a firm to be included in this estimation). We classify industries with an above-median sensitivity to changes in local macroeconomic conditions as "high growth." The presumption is that tax reforms do not prompt growth across all industries, despite possibly stimulating GDP growth in aggregate. Firms operating in industries whose growth is relatively "uncorrelated" with economic conditions are less likely to alter their leverage because of better growth opportunities after the tax reform.

Regression 1 of Table 7 presents the results. In particular, interactions between the tax variables and the "high growth" indicator are added to our baseline specifications. We find some of those interaction terms to be statistically significant. More importantly, the tax variables are also statistically significant, suggesting that firms do alter their leverage ratio in response to tax rate changes even when these tax changes do not have a sizeable effect on their growth opportunities.

As a second experiment, we do keyword searches to identify industries with countercyclical revenues. The resulting set of "countercyclical" industries consists of agricultural production crops (2-digit Standard Industrial Classification

\footnotetext{
${ }^{13}$ Other country- and firm-level control variables do not display different trends following tax increases or decreases.
} 
TABLE 7

Macroeconomic Conditions and the Effects of Taxes on Capital Structure

HIGH_GROWTH is one of the two following variables: The first is an indicator for Above-Median Sensitivity of MB Change to GDP_GROWTH, defined as the slope coefficient from an industry-by-industry regression of the annual change in MB on GDP growth. The second is an indicator named Cyclical Industry, which is 1 for any 2-digit SIC industry whose performance is perceived to be positively related to the overall market and 0 for noncyclical industries. In column 3 , we replace each country's tax rates with the tax rates of its OECD geographic neighbor. If a country shares borders with multiple countries, we use the tax rates of the OECD neighbor that follows the country in question in alphabetical order. The regressions include the same control variables as Table 2 (not reported for space reasons). The $t$-statistics based on standard errors adjusted for two-way clustering (i.e., country-year cells and firm) are shown in parentheses below the coefficient estimates; ${ }_{\star \star \star \star},{ }^{\star \star}$, and ${ }^{*}$ indicate significance at the $1 \%, 5 \%$, and $10 \%$ levels, respectively. Note: In regressions 1 and 2 , the High Growth indicator drops out from the model due to the inclusion of firm-fixed effects.

\begin{tabular}{|c|c|c|c|}
\hline \multirow[b]{3}{*}{ Exolonoto Korioblo } & \multicolumn{2}{|c|}{ HIGH_GROWTH = Dummy for } & \multirow[b]{2}{*}{$\begin{array}{l}\text { Taxes in } \\
\text { Neighboring } \\
\text { Countries }\end{array}$} \\
\hline & $\begin{array}{l}\text { Above-Median } \\
\text { Sensitivity of } \\
\text { MB Change to } \\
\text { GDP_GROWTH }\end{array}$ & $\begin{array}{l}\text { Cyclical } \\
\text { Industry }\end{array}$ & \\
\hline & 1 & 2 & 3 \\
\hline CORPORATE_TAX & $\begin{array}{l}0.313^{\star \star \star} \\
(4.78)\end{array}$ & $\begin{array}{l}0.383^{\star \star \star} \\
(4.61)\end{array}$ & $\begin{array}{l}-0.047 \\
(-0.85)\end{array}$ \\
\hline PERSONAL_INTEREST_TAX & $\begin{array}{l}-0.110^{\star *} \\
(-2.26)\end{array}$ & $\begin{array}{l}-0.115^{\star *} \\
(-2.08)\end{array}$ & $\begin{array}{l}-0.166^{\star} \\
(-1.72)\end{array}$ \\
\hline PERSONAL_DIVIDEND_TAX & $\begin{array}{l}0.151^{\star \star \star} \\
(4.44)\end{array}$ & $\begin{array}{l}0.139^{\star \star \star} \\
(3.85)\end{array}$ & $\begin{array}{l}-0.004 \\
(-0.11)\end{array}$ \\
\hline $\begin{array}{l}\text { HIGH_GROWTH } \\
\times \text { CORPORATE_TAX }\end{array}$ & $\begin{array}{l}0.163^{* \star \star} \\
(2.74)\end{array}$ & $\begin{array}{l}0.020 \\
(0.34)\end{array}$ & \\
\hline $\begin{array}{l}\text { HIGH_GROWTH } \\
\quad \times \text { PERSONAL_INTEREST_TAX }\end{array}$ & $\begin{array}{l}-0.140^{\star * *} \\
(-3.37)\end{array}$ & $\begin{array}{l}-0.082^{*} \\
(-1.76)\end{array}$ & \\
\hline $\begin{array}{l}\text { HIGH_GROWTH } \\
\quad \times \text { PERSONAL_DIVIDEND_TAX }\end{array}$ & $\begin{array}{l}-0.022 \\
(-1.01)\end{array}$ & $\begin{array}{c}0.002 \\
(0.08)\end{array}$ & \\
\hline $\begin{array}{l}\text { Control variables } \\
\text { Bankruptcy reform dummies } \\
\text { Firm-fixed effects } \\
\text { Year-fixed effects }\end{array}$ & $\begin{array}{l}\text { Yes } \\
\text { Yes } \\
\text { Yes } \\
\text { Yes }\end{array}$ & $\begin{array}{l}\text { Yes } \\
\text { Yes } \\
\text { Yes } \\
\text { Yes }\end{array}$ & $\begin{array}{l}\text { Yes } \\
\text { Yes } \\
\text { Yes } \\
\text { Yes }\end{array}$ \\
\hline $\begin{array}{l}\text { No. of obs. } \\
\text { Adj. } R^{2}\end{array}$ & $\begin{array}{c}251,250 \\
0.70\end{array}$ & $\begin{array}{c}241,837 \\
0.70\end{array}$ & $\begin{array}{c}204,029 \\
0.69\end{array}$ \\
\hline
\end{tabular}

(SIC) code: 01); agriculture production livestock and animal specialties (02); agricultural services (07); fishing, hunting, and trapping (09); food and kindred products (20); tobacco products (21); chemicals and allied products (28); electric, gas, and sanitary services (49); wholesale trade-nondurable goods (51); food stores (54); health services (80); legal services (81); and educational services (82). As the revenues of firms in those industries tend to be uncorrelated with the business cycle, it is unlikely that tax reforms would lead to leverage changes because of an effect on these firms' growth opportunities.

Thus, in our second test, we identify "high growth" firms as those from any industry other than the "countercyclical" ones. The results are presented in regression 2. Those results show that firms operating in countercyclical industries alter their leverage in response to tax changes. These results are, once again, consistent with the idea that firms change their leverage in response to tax changes because those reforms affect the tax incentives to use debt.

An alternative way to mitigate the possibility that our results reflect a growth effect rather than a tax effect is by looking at tax changes in neighboring countries. To the extent that economic cycles are correlated within a given geographic area but tax reforms are not, if the changes in leverage that we are capturing reflect changes in macroeconomic conditions, we should find that leverage responds to 
tax changes in neighboring countries. However, if the documented changes in leverage primarily reflect the tax savings associated with the tax deductibility of interest, we should not find leverage to change following tax changes in neighboring countries.

To test this prediction, in regression 3 of Table 7 we replace each country's tax rates with the tax rates of its OECD geographic neighbor. If a country shares borders with multiple countries, we use the tax rates of the OECD neighbor that follows the country in question in alphabetical order. As regression 3 shows, there is very little evidence that tax changes in neighboring countries affect leverage. While this result is inconsistent with a growth channel explanation of leverage changes, it is consistent with a tax benefits story.

\section{Other Robustness Tests}

In this section we test the robustness of our results by controlling for a host of additional factors. (We add these additional control variables to the baseline regression model, regression 1 of Table 2.) Results of these tests are not tabulated due to space constraints.

First, we consider the overall taxation of equity income. Since equity income includes both dividends and capital gains, it is reasonable to consider using a blended average of taxes on dividends and capital gains in our main regressions. We obtain data on capital gain taxes from Becker, Jacob, and Jacob (2013). Those data are available only for 25 of the OECD countries and only for the period of 1990-2008 (for this reason, capital gain taxes were not included in the main analyses). Consistent with the results in Table 2, we find that the coefficient of the average of capital gain and dividend tax rates is positive and statistically significant.

Second, we recognize that a number of countries in the sample have an imputation tax system. Under an imputation system, the taxes paid by the firm on its profits are (fully or in part) credited against any tax liability at the shareholder level. When we construct the dividend tax variable for our sample, we try to account for such credits when detailed information about the imputation rules is available. However, this approach may not be comprehensive. Therefore, to further control for any remaining impact of different imputation systems on capital structure, we interact each of the tax variables with a dummy variable denoting whether a given country (in a given year) has either a full or partial imputation system. We gather information on the type of tax system in place from the OECD. In line with the prediction that credits for corporate taxes reduce the tax incentives to use debt, we find that the effect of both corporate taxes and personal dividend taxes on leverage is generally smaller when a full or a partial imputation tax system is in place. Importantly, for the overall sample, the effect of taxes remains significant after adding these controls.

Third, we note that taxes should have a greater impact on capital structure choices in countries with low levels of tax evasion. At the extreme, if agents could evade taxes with no penalty, capital structure should not change following tax changes. To test this prediction, we sort countries into 3 groups by the prevalence of tax evasion: the terciles of countries with the highest, intermediate, and lowest 
levels of tax evasion. For this purpose, we employ the assessment of the prevalence of tax evasion in a country in 2002 as reported by the World Economic Forum. This index is constructed from a survey of corporate executives and their assessments of how rampant tax evasion is in their countries. We find that tax changes have no effect on capital structure in countries in the highest tercile of tax evasion. By contrast, taxes matter progressively more (in both statistical and economic terms) as tax evasion declines. For example, the coefficient on corporate taxes increases from 0.037 in the high tax evasion country tercile to 0.199 in the intermediate tax evasion country tercile, and it increases again to 0.526 in the low tax evasion country tercile.

Fourth, we add controls for the de facto quality of the legal system. The first proxy we use pertains to enforcement of the law, while the second relates to government's stance toward business (La Porta, Lopez-de-Silanes, Shleifer, and Vishny (1998)). These two proxies are taken from the Political Risk Services Group. ${ }^{14}$ The first proxy, LAW_AND_ORDER, is an "assessment of the strength and impartiality of the legal system ... [and] of popular observance of the law" (http://www.prsgroup.com/wp-content/uploads/2012/11/icrgmethodology .pdf, p. 5). The second proxy, CORRUPTION,

is an assessment of corruption within the political system.... The most common form of corruption met directly by business is financial corruption in the form of demands for special payments and bribes connected with import and export licenses, exchange controls, tax assessments, police protection, or loans. (http://www.prsgroup.com/wp-content/ uploads/2012/11/icrgmethodology.pdf, p. 4)

We find that changes in the quality of the legal system are somewhat related to changes in leverage. However, the effect of tax changes on leverage is robust to controlling for changes in the quality of the legal system.

Fifth, we control for governance reforms to mitigate the concern that the tax effect we document is driven by changes in agency considerations through time. For this purpose, for each country we identify the introduction of the first "corporate governance" code using information available from the European Corporate Governance Institute (see http://www.ecgi.org/codes/all_codes.php). We add a separate governance reform indicator for each country to allow each reform to have a unique effect on leverage. We find that the addition of controls for governance reforms does not change the sign or statistical significance of the tax variables. Therefore, it is unlikely that the documented effect of taxation on capital structure reflects changes in agency costs through time.

Sixth, we assess the extent to which the results may be driven by a single country outlier. For this purpose, we reestimate the regression specifications in Table 2 by dropping 1 country at a time, resulting in 29 new regression specifications. Consistent with the results in Table 2, the corporate tax variable has a positive coefficient in each of the 29 specifications, ranging from 0.217 to 0.467 , with $t$-statistics ranging from 3.61 to 6.15 . The coefficient of the personal interest tax variable is negative in each specification, ranging from -0.084 to -0.223 ,

\footnotetext{
${ }^{14}$ See http://epub.prsgroup.com/country-database/country-data
} 
with $t$-statistics ranging from -1.85 to -4.73 . The coefficient of the personal dividend tax variable ranges from 0.113 to 0.158 , with $t$-statistics ranging from 3.49 to 4.59. Finally, the coefficient of the Miller tax index ranges from 0.144 to 0.220, with $t$-statistics ranging from 4.69 to 5.92. Thus, the results in Table 2 are not driven by any single country outlier.

Seventh, we explicitly control for bankruptcy risk by adding a modified Z-SCORE (MacKie-Mason (1990), Graham (1996a)). We find a negative correlation between the modified Z-SCORE and leverage. Once again, the tax results are robust to the inclusion of this additional control variable.

Eighth, we assess the robustness of our results to controlling for median industry leverage. We do so as Leary and Roberts (2014) document that peers' (i.e., industry) leverage is an important determinant of capital structure choices. While we confirm their result, we also document that taxes remain significant after controlling for peers' leverage.

Last but not least, we replicate the main specification in Table 2 with 1-year lags of all independent variables. The tax results are robust to this change as well.

\section{Conclusions}

In this paper, we examine the effect of taxes on corporate capital structure by using a multitude of corporate and personal tax changes in 29 OECD countries over the years 1981-2009. In line with theoretical predictions, we find both corporate and personal taxes to be significant determinants of capital structure choices. Compared with the prior literature, we provide more general evidence for Miller's (1977) assertion that personal taxes matter for capital structure in a broad sample.

In our sample, firms tend to increase their leverage when corporate taxes or personal taxes on dividend income increase and tend to reduce leverage when personal taxes on interest income increase. Ex post, across all OECD countries, taxes appear to be as important as other traditional variables in explaining capital structure choices.

Additionally, corporate taxes have an even larger impact among profitable firms and firms with positive tax outlays, while personal taxes play a larger role among firms that are more likely to have an individual as the marginal investor. These findings are in line with a tax explanation, since it would be unlikely for these subsets of firms to respond more following tax reforms if a nontax explanation was driving our results.

\section{References}

Armour, J., and D. Cumming. "Bankruptcy Law and Entrepreneurship." American Law and Economics Review, 10 (2008), 303-350.

Auerbach, A. J., and K. A. Hassett. "The 2003 Dividend Tax Cuts and the Value of the Firm: An Event Study.” In Taxing Corporate Income in the 21st Century, A. J. Auerbach, J. R. Hines, Jr., and J. Slemrod, eds. New York, NY: Cambridge University Press (2007).

Ayers, B. C.; C. B. Cloyd; and J. R. Robinson. "The Effect of Shareholder-Level Dividend Taxes on Stock Prices: Evidence from the Revenue Reconciliation Act of 1993." Accounting Review, 77 (2002), 933-947. 
Becker, B.; M. Jacob; and M. Jacob. "Payout Taxes and the Allocation of Investment." Journal of Financial Economics, 107 (2013), 1-24.

Bell, L., and T. Jenkinson. "New Evidence on the Impact of Dividend Taxation on the Identity of the Marginal Investor.” Journal of Finance, 57 (2002), 1321-1346.

Booth, L.; V. Aivazian; A. Demirgüç-Kunt; and V. Maksimovic. "Capital Structures in Developing Countries." Journal of Finance, 56 (2001), 87-130.

Brown, J. R.; N. Liang; and S. Weisbenner. "Executive Financial Incentives and Payout Policy: Firm Responses to the 2003 Dividend Tax Cut.” Journal of Finance, 62 (2007), 1935-1965.

Campello, M. "Taxes and Capital Structure: Do Investors' Taxes Matter? Evidence from the Tax Reform Act of 1986." Unpublished Dissertation Chapter, University of Illinois at Urbana-Champaign (2001).

Campello, M., and E. Giambona. "Real Assets and Capital Structure." Journal of Financial and Quantitative Analysis, 48 (2013), 1333-1370.

DeAngelo, H., and R. W. Masulis. "Optimal Capital Structure under Corporate and Personal Taxation." Journal of Financial Economics, 8 (1980), 3-29.

Denis, D. J., and V. T. Mihov. "The Choice among Bank Debt, Non-Bank Private Debt, and Public Debt: Evidence from New Corporate Borrowings." Journal of Financial Economics, 70 (2003), 3-28.

Desai, M. A.; A. Dyck; and L. Zingales. "Theft and Taxes." Journal of Financial Economics, 84 (2007), 591-623.

Desai, M. A.; C. F. Foley; and J. R. Hines Jr. "A Multinational Perspective on Capital Structure Choice and Internal Capital Markets.” Journal of Finance, 59 (2004), 2451-2487.

Dhaliwal, D.; L. K. Krull; and O. Z. Li. "Did the 2003 Tax Act Reduce Cost of Equity Capital?" Journal of Accounting and Economics, 43 (2007), 121-150.

Dhaliwal, D.; L. K. Krull; O. Z. Li; and W. Moser. "Dividend Taxes and Implied Cost of Equity Capital." Journal of Accounting Research, 43 (2005), 675-708.

Fama, E. F., and K. R. French. "Capital Structure Choices." Critical Finance Review, 1 (2012), 59-101.

Fan, J. P. H.; S. Titman; and G. Twite. "An International Comparison of Capital Structure and Debt Maturity Choices.” Journal of Financial and Quantitative Analysis, 47 (2012), 23-56.

Farrar, D. F., and L. Selwyn. "Taxes, Corporate Policy, and Return to Investors.” National Tax Journal, 20 (1967), 444-454.

Fisher, T. C. G., and J. Martel. "The Effect of Bankruptcy Reform on the Number of Corporate Reorganization Proposals.” Canadian Public Policy, 29 (2003), 339-350.

Galgano, F. Diritto Commerciale: Le Società, 4th ed. Bologna, Italy: Zanichelli (1994).

Givoly, D.; C. Hahn; A. R. Ofer; and O. Sarig. "Taxes and Capital Structure: Evidence from Firms' Response to the Tax Reform Act of 1986." Review of Financial Studies, 52 (1992), 331-355.

Graham, J. R. "Debt and the Marginal Tax Rate.” Journal of Financial Economics, 41 (1996a), 41-73.

Graham, J. R. "Proxies for the Marginal Tax Rate." Journal of Financial Economics, 42 (1996b), $187-221$.

Graham, J. R. "Do Personal Taxes Affect Corporate Financing Decisions?" Journal of Public Economics, 73 (1999), 147-185.

Graham, J. R. "Taxes and Corporate Finance: A Review.” Review of Financial Studies, 16 (2003), 1074-1128.

Hovakimian, A.; T. C. Opler; and S. Titman. "The Debt-Equity Choice: An Analysis of Issuing Firms." Journal of Financial and Quantitative Analysis, 36 (2001), 1-24.

Jung, K.; Y. Kim; and R. Stulz. "Timing, Investment Opportunities, Managerial Discretion, and the Security Issue Decision.” Journal of Financial Economics, 42 (1995), 159-185.

Korkeamäki, T. P.; Y. Koskinen; and T. Takalo. "Phoenix Rising: Legal Reforms and Changes in Valuations in Finland during the Economic Crisis." Journal of Financial Stability, 3 (2007), 33-58.

La Porta, R.; F. Lopez-de-Silanes; A. Shleifer; and R. W. Vishny. "Law and Finance.” Journal of Political Economy, 106 (1998), 1113-1155.

Leary, M. T., and M. R. Roberts. "Do Peer Firms Affect Corporate Financial Policy?" Journal of Finance, 69 (2014), 139-178.

MacKie-Mason, J. K. "Do Taxes Affect Corporate Financing Decisions?" Journal of Finance, 45 (1990), 1471-1493.

Miller, M. H. "Debt and Taxes.” Journal of Finance, 32 (1977), 261-275.

Modigliani, F., and M. H. Miller. "Corporate Income Taxes and the Cost of Capital: A Correction" (in Communications). American Economic Review, 53 (1963), 433-443.

Myers, S. C. "Taxes, Corporate Financial Policy and the Return to Investors: Comment." National Tax Journal, 20 (1967), 455-462. 
Myers, S. C. “The Capital Structure Puzzle.” Journal of Finance, 39 (1984), 575-592.

Öztekin, Ö., and M. Flannery. "Institutional Determinants of Capital Structure Adjustment Speeds." Journal of Financial Economics, 103 (2012), 88-112.

Petersen, M. A. "Estimating Standard Errors in Finance Panel Data Sets: Comparing Approaches." Review of Financial Studies, 22 (2009), 435-480.

Philippe \& Partners and Deloitte \& Touche. "Bankruptcy and a Fresh Start: Stigma on Failure and Legal Consequences of Bankruptcy.” Working Paper, Brussels (2002).

Rajan, R., and L. Zingales. "What Do We Know About Capital Structure? Some Evidence from International Data." Journal of Finance, 50 (1995), 1421-1460.

Richter, T. "The New Czech Insolvency Act-New Insolvency Regime for Czech Corporate Debtors and Their Creditors.” Butterworths Journal of International Banking and Financial Law, 21 (2006), 271-272.

Rohrlich, C. “The New Deal in Corporation Law.” Columbia Law Review, 35 (1935), 1167-1195.

Rosenbaum, P. R., and D. B. Rubin. "The Central Role of the Propensity Score in Observational Studies for Causal Effects." Biometrika, 70 (1983), 41-55.

Twite, G. "Capital Structure Choices and Taxes: Evidence from the Australian Dividend Imputation Tax System.” International Review of Finance, 4 (2001), 217-234. 